\title{
The influence of flunixin on the elimination and milk residual patterns of oxytetracycline in dairy goats
}

\author{
Mohamed Atef, Abo-Baker Y. I. EL-Gendi, Nehal A. Afifi, \\ Khaled Abo-EL-Sooud*, and Hesham Y. EL-Zorba \\ Department of Pharmacology, Faculty of Veterinary Medicine, Cairo, Giza, Egypt
}

\begin{abstract}
ATEF, M., A.-B. Y. I. EL-GENDI, N. A. AFIFI, K. ABO-EL-SOOUD, H. Y. ELZORBA: The influence of flunixin on the elimination and milk residual patterns of oxytetracycline in dairy goats. Vet. arhiv 89, 155-168, 2019.
\end{abstract}

\section{ABSTRACT}

This research assessed the impact of flunixin meglumine (FM) co-administration on the elimination and milk residual properties of oxytetracycline (OTC) in dairy goats. OTC was administered via single intravenous (i/v) and intramuscular (i/m) injections at a dose of $10 \mathrm{mg} / \mathrm{kg}$ body mass (b.m.). Serum, urine, milk and ruminal juice were analysed using high-performance liquid chromatography (HPLC). The OTC serum concentrations were higher than the MIC for 12 hours against most susceptible pathogens in both groups. The half-lives of the distribution $\left(\mathrm{T}_{1 / 2 \alpha}\right)$ and elimination $\left(\mathrm{T}_{1 / 2 \beta}\right)$ of OTC were 0.24 and 5.79 hours, respectively. The total body clearance was significantly increased in the FM coadministered groups. Following $\mathrm{i} / \mathrm{m}$ injection, the absorption half-life $\left(\mathrm{T}_{1 / 2 a \mathrm{~b}}\right)$ with the maximum absorption time $\left(\mathrm{T}_{\max }\right)$ revealed a rapid absorption rate. Furthermore, the systemic bioavailability ( $\mathrm{F} \%$ ) after $\mathrm{i} / \mathrm{m}$ was $107.2 \%$, indicating complete absorption from the muscular tissues. The bounded fraction of OTC with serum proteins was $18.73 \%$. FM significantly decreases OTC concentration in milk and ruminal juice. OTC is eliminated primarily through the kidneys and to a lesser extent via milk and ruminal juice in dairy goats. Milk obtained from OTC treated goats may not be safe for human consumption two days post administration. Concomitantly, the use of FM with OTC may necessitate the surveillance and optimization of OTC dosage.

Key words: oxytetracycline; flunixin meglumine; elimination; milk; residues; goats

\section{Introduction}

Newly combined formulations of antimicrobials with non-steroidal anti-inflammatory drugs (NSAIDs) have serious effects on elimination and residual patterns, especially in milk-producing animals. Information on milk residual patterns in these veterinary combinations is lacking (GROPPO et al., 2004; TSIVOU et al., 2005). Antibiotic residues

\footnotetext{
${ }^{*}$ Corresponding author:

Khaled Abo-EL-Sooud, Department of Pharmacology, Faculty of Veterinary Medicine, Cairo University P.O. Box 12211, Giza, Egypt, Phone: +201 066756 870; Fax: +202 35725 240; E-mail: kasooud@cu.edu.eg
} 
M. Atef et al.: The influence of flunixin on the elimination and milk residual patterns of oxytetracycline in dairy goats

in animal products may significantly enhance the transfer of bacterial resistance to humans, potentially resulting in the failure of antimicrobial therapy in human (ATTAIE et al., 2016). The effect of this interaction on withdrawal times in dairy animals has not been confirmed (KUKANICH et al., 2005). Oxytetracycline (OTC) is a wide-spectrum chemotherapeutic agent that works against most pathogenic bacteria and certain other blood protozoal parasites (GIGUÈRE et al., 2013). In veterinary medicine, OTC is extensively used due to its broad-spectrum activity and appropriate tissue-penetrating aspects (GRAIGMILL et al., 2000). NSAIDs are commonly used with antibacterials to combat systemic infections associated with febrile diseases (MESTORINO et al., 2007). Flunixin meglumine (FM) is a NSAID and is a very potent inhibitor of the enzyme prostaglandin cyclooxygenase (COX), resulting in the inhibition of prostaglandin synthesis (LANDONI et al., 1995). Co-administration of FM and the broad-spectrum antibiotic OTC provided a greater benefit in pneumonia and in field cases of acute respiratory diseases (DOHERTY et al., 2001). Previous studies reported on the pharmacokinetic interactions between FM with fluoroquinolones and cephalosporins when used concomitantly (LOCKWOOD et al., 2003; HALLOY et al., 2006). Nevertheless, there is inadequate information on the effects of FM on the different elimination pathways and milk residues of OTC, especially in dairy animals. The aim of the present study was to evaluate the influence of concomitant administration of FM on the elimination patterns of OTC from the kidneys, milk and ruminal juice after $\mathrm{i} / \mathrm{v}$ and $\mathrm{i} / \mathrm{m}$ co-administration in dairy goats. Moreover, the milk withdrawal time of OTC in dairy goats was estimated.

\section{Materials and methods}

Drugs. Oxytetracycline (Terramycin $\left.{ }^{\circledR} 100\right)$ : is an injectable preparation containing $100 \mathrm{mg} / \mathrm{mL}$ OTC hydrochloride as a magnesium complex in aqueous solution. The drug is supplied by Pfizer, Egypt and is indicated for intramuscular and intravenous injection.

Flunixin meglumine $\left(\right.$ Finadyne $\left.^{\circledR}\right)$ : is a product of Schering - Plough, U.S.A., available as a sterile injection at $50 \mathrm{mg} / \mathrm{mL}$.

Oxytetracycline - flunixin combination: For every $100 \mathrm{~mL}$ of Pfizer Terramycin $(100$ $\mathrm{mg} / \mathrm{mL}) 40 \mathrm{~mL}$ of FM weas added as $(50 \mathrm{mg} / \mathrm{mL})$ to obtain a ratio of $(10 \mathrm{mg}$ OTC $+2 \mathrm{mg}$ FM) for intravenous and intramuscular injection. No incompatibility was observed with the addition of FM.

Animals. Ten clinically healthy dairy goats of 2-2.5 years weighing $25-30 \mathrm{~kg}$ each, were used. The animals were fed a drug-free diet and water ad libitum in a hygienic environment and each goat was thoroughly milked twice daily. The institutional animal care and use committee (IACUC) of Cairo University approved the study (Feb-2017).

Experimental plan and sampling. The goats were divided into two groups (five goats each). Blood, urine, milk and ruminal juice samples free of drugs were collected before 
M. Atef et al.: The influence of flunixin on the elimination and milk residual patterns of oxytetracycline in dairy goats

drug administration. The goats were left for 30 days between each injection to ensure the complete elimination of the drugs.

Intravenous (i/v) injection. Each of the 5 goats was injected with OTC $(10 \mathrm{mg} / \mathrm{kg}$ b.m.) in the right jugular vein. Forty-five days later, these animals were injected with the same dose of OTC in combination with FM at a dose of $12 \mathrm{mg} / \mathrm{kg}$ b.m. via the same route.

Intramuscular $(\mathrm{i} / \mathrm{m}$ ) injection. The same doses of OTC and OTC + FM combination were injected into the left gluteal muscle with an interval of forty-five days in between.

Blood samples. Two millilitres of blood was collected from the left jugular vein via catheters just before and at 5,10, 20, and 30 minutes and, 1, 2, 4, 6, 8, 10, 12, 24, 48 and 72 hours after drug administration. Blood samples were allowed to clot at room temperature and the sera were separated by centrifugation at 3000 r.p.m. for 25 minutes, and stored at $-20{ }^{\circ} \mathrm{C}$ until assayed.

Urine samples. Urine samples were collected using rubber balloon catheters fixed inside the bladder, that allowed urine to flow. The bladder was emptied before drug administration, and urine samples were collected 15 and 30 minutes and, 1, 2, 4, 6, 8, $10,12,24,48$ and 72 hours. post-injection. The urine samples taken at 15 minutes were discarded. All urine samples were stored at $-20{ }^{\circ} \mathrm{C}$ until assayed.

Milk samples. Samples were collected by hand milking. The udder was completely evacuated before the injection and after each sampling. Samples were taken at 15 and 30 minutes and, 1, 2, 4, 6, 8, 10, 12, 24, 48 and 72 hours following drug administration. The milk samples taken at 15 minutes were discarded. Complete evacuation of the udder was carried out after each sampling.

Ruminal juice samples. Samples were obtained via a stomach tube connected to a vacuum pump. Samples were taken before and 1, 2, 4, 6, and 8 hours after the injections.

Analytical procedure. The concentrations of OTC in the serum and different body fluids were analyzed using HPLC (Shimadzu modular system - Japan) with the reversed-phase separation method of KNOX and JAURAND (1979). The mobile phase was composed of $30 \% \mathrm{~N}$, N-dimethyl formamide and $70 \%$ water containing sodium citrate $(0.013 \mathrm{M})$, potassium nitrate $(0.01 \mathrm{M})$, disodium EDTA $(0.001 \mathrm{M})$ and citric acid monohydrate $(0.05$ $\mathrm{M})$ with the $\mathrm{pH}$ adjusted to 3.5 using phosphoric acid. The mobile phase was degassed using an ultrasonic cleaner (Bransonic, USA) for one hour. The flow rate was $0.5 \mathrm{~mL} /$ $\min$. The concentrations were detected at $365 \mathrm{~nm}$ with an ultraviolet detector.

Sample preparation. One $\mathrm{mL}$ of sample was deproteinated with $0.25 \mathrm{~mL}$ of $15 \%$ trichloroacetic acid, according to ASZALOS, 1985. The mixture was vortexed for one minute, placed on ice for 15 minutes and centrifuged for 15 minutes at 3000 r.p.m. Methanol was added to the milk samples (1:1), and the mixture was vortexed for one minute, placed on ice for 15 minutes and centrifuged at 3000 r.p.m. for 30 minutes. Urine 
M. Atef et al.: The influence of flunixin on the elimination and milk residual patterns of oxytetracycline in dairy goats

samples were diluted to 1:10 using HPLC-grade water, and then $0.5 \mathrm{~mL}$ of the supernatant was mixed with an equal volume of methanol and centrifuged for 20 minutes. Ruminal juice samples were centrifuged at 3000 r.p.m. for 30 minutes. Twenty microlitres of the clear supernatant was diluted with $0.8 \mathrm{~mL}$ of HPLC-grade water, mixed and centrifuged, and $0.5 \mathrm{~mL}$ of the supernatant, with an equal volume of methanol, was centrifuged for 15 minutes. Twenty microlitres of the clear supernatant was injected into the HPLC column from all types of samples.

Validation of the analytical method. The precision and accuracy of the method were evaluated by repetitive analysis of the different samples $(n=6)$, spiked with different, known concentrations of OTC. Intra-assay variations were determined by measuring six replicates $(n=6)$ of three standard samples used for calibration curves. The calibration curve provided excellent linearity with correlation coefficients $(\mathrm{r} 2)$ of $>0.98$ in the present study, and the linearity was confirmed by the test of lack of fit $(\mathrm{P}=0.756)$. The intra-assay variation coefficient $(\mathrm{CV})$ was $4 \%$. Inter-assay precision was determined by assaying three standard samples on three separate days. The inter-assay CV was $<5 \%$ for serum. Recovery of OTC from all samples was found to be $96 \%$. The limit of detection (LOD) and limit of quantification (LOQ) of OTC were 0.005 and $0.01 \mu \mathrm{g} / \mathrm{mL}$, respectively.

Estimation of protein binding. After the protein-bound part is precipitated in the serum, the free unbound drug is the part that part that is measured by HPLC and gives the measured area under the curve. Differences in the area under the curve between the solution of OTC alone or combined with FM in phosphate buffer, and that of serum at the same concentrations were used to calculate the protein binding affinity of OTC according to CRAIG and SUH (1980).

Pharmacokinetic analysis. A computerized curve-stripping program (Rstrip, Micromath, Scientific Software, Salt Lake City, Utah, USA) was used for data analysis for each animal. Following intravenous injection, the disposition curves of OTC that express the decline in serum drug concentration as a function of time was best described by the two-compartmental open model (biexponential expression):

$\mathrm{Cp}=\mathrm{Ae}^{-\alpha \mathrm{t}}+\mathrm{Be}^{-\beta \mathrm{t}}$

where

$\mathrm{Cp}$ is the drug concentration in serum at time $\mathrm{t}$;

$\mathrm{A}$ and $\mathrm{B}$ are the intercepts of the distribution and elimination phases, respectively, with the concentration axis expressed as $\mu \mathrm{g} / \mathrm{mL}$;

$\alpha$ and $\beta$ are the distribution and elimination rate constants, respectively expressed in units of reciprocal time $\left(\mathrm{h}^{-1}\right)$;

$\mathrm{e}$ is the natural logarithm base. 
M. Atef et al.: The influence of flunixin on the elimination and milk residual patterns of oxytetracycline in dairy goats

The apparent volume of distribution was calculated according to BAGGOT (1977) via the area $\left(\mathrm{V}_{\text {darea }}\right)$, and steady state $\left(\mathrm{V}_{\text {dss }}\right)$ methods.

Following $\mathrm{i} / \mathrm{m}$ injection, the peak of OTC concentration $\left(\mathrm{C}_{\max }\right)$ and time to peak concentration $\left(\mathrm{T}_{\max }\right)$ were determined. This program also calculated non-compartmental parameters by using the statistical moment theory. The elimination half-life $\left(\mathrm{T}_{1 / 2} \mathrm{el}\right)$ was calculated as $\ln _{2} / \beta$. The areas under the concentration-time curves (AUC) were calculated according to the trapezoidal rule (GIBALDI and PIERRIER, 1982). The mean residence time (MRT) for OTC was calculated as AUMC/AUC, where AUMC is the area under the first moment curve and AUC is the area under the curve. The systemic bioavailability is the fraction of the intramuscular dose absorbed, and is calculated as $\mathrm{F} \%=\left(\mathrm{AUC}_{\mathrm{i} / \mathrm{m}} /\right.$ $\left.\mathrm{AUC}_{\mathrm{i} / \mathrm{v}}\right) \times 100$.

The body clearance $\left(\mathrm{Cl}_{\text {tot }}\right)$ is the volume of blood cleared of the drug by various elimination processes (biotransformation and excretion) per unit of time, and is calculated as follows:

$$
\mathrm{Cl}_{\mathrm{tot}}=\mathrm{K}^{\mathrm{el}} \mathrm{X} \mathrm{Vc} \quad \mathrm{L} \mathrm{kg}^{-1} \mathrm{~h}^{-1}
$$

Statistical analysis. The results are tabulated as the mean \pm SE. The significance of differences between the mean concentrations and kinetic parameters of the groups treated with the combination, and those given the antibiotic alone were analysed statistically using Student's $t$-test in SPSS 16.0 (SPSS Inc., Chicago, IL, USA).

\section{Results}

The mean serum concentration-time curves for OTC after $\mathrm{i} / \mathrm{v}$ and $\mathrm{i} / \mathrm{m}$ injections, either alone or combined with FM, are presented in Figs 1 and 2. The pharmacokinetic values following intravenous injection are summarized in Table 1. Following $\mathrm{i} / \mathrm{v}$ injection, the OTC serum concentration declined in a biexponential mode, indicating the distribution and elimination phases and mitigating the best choice of a two-compartment model for analysis. The half-lives of the distribution and elimination of OTC were significantly decreased with co-administration of FM. Furthermore, the apparent volumes of distribution of OTC combined with FM showed values half of those calculated after OTC administration alone. The pharmacokinetic parameters of OTC after i/m injection (Table 1) showed a comparatively narrow variation between the single and combined formulation with FM, versus the case of intravenous administration. OTC was largely eliminated in urine after both single and combined administration with FM (Table. 2). However, the tested drug was excreted in small concentrations in the ruminal juice and milk, with comparatively higher values in both fluids after the sole administration of OTC than in OTC combined with FM (Tables 3 and 4). 
M. Atef et al.: The influence of flunixin on the elimination and milk residual patterns of oxytetracycline in dairy goats

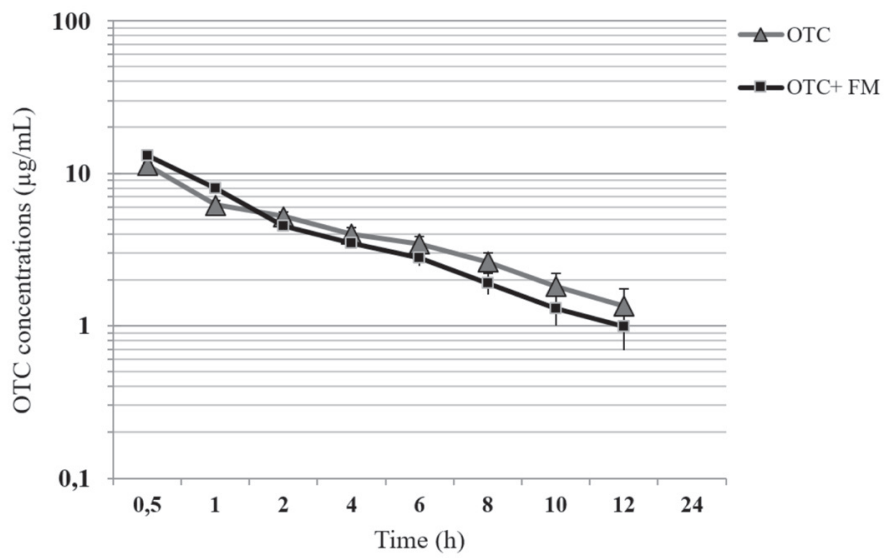

Fig. 1. Serum concentrations of oxytetracycline ( $10 \mathrm{mg} / \mathrm{kg} \mathrm{b.m}$.) following single intravenous injection alone and with flunixin meglumine $(12 \mathrm{mg} / \mathrm{kg} \mathrm{b.m}$.) coadministration in dairy goats

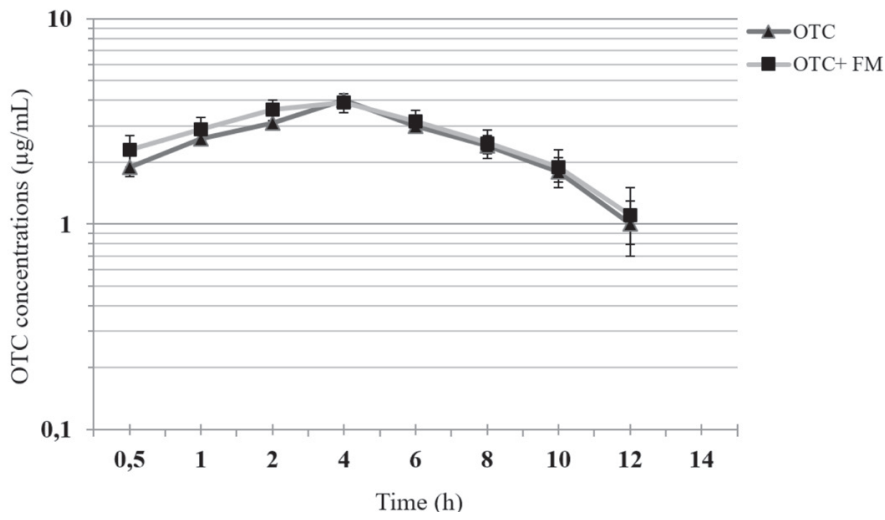

Fig. 2. Serum concentrations of oxytetracycline $(10 \mathrm{mg} / \mathrm{kg} \mathrm{b.m}$.) following single intramuscular injection alone and with flunixin meglumine $(12 \mathrm{mg} / \mathrm{kg} \mathrm{b.m.)} \mathrm{coadministration} \mathrm{in} \mathrm{dairy} \mathrm{goats}$

Table 1. Mean kinetic parameters of OTC alone (10 mg/kg b.m.) and OTC + flunixin combination $(12 \mathrm{mg} / \mathrm{kg}$ b.m.) following single intravenous and intramuscular injections in goats $(\mathrm{n}=5)$

\begin{tabular}{|c|c|c|c|c|c|}
\hline \multirow[b]{2}{*}{ Parameter } & \multirow[b]{2}{*}{ Unit } & \multicolumn{2}{|c|}{ Intravenous } & \multicolumn{2}{|c|}{ Intramuscular } \\
\hline & & OTC & $\mathrm{OTC}+\mathrm{FM}$ & OTC & $\mathrm{OTC}+\mathrm{FM}$ \\
\hline$\alpha\left(\mathrm{k}_{\mathrm{ab}}\right)$ & $\mathrm{h}^{-1}$ & $2.95 \pm 0.048$ & $4.22 \pm 0.38^{* *}$ & $1.06 \pm 0.02$ & $0.91 \pm 0.018^{* *}$ \\
\hline $\mathrm{T}_{1 / 2 \alpha}\left(\mathrm{T}_{1 / 2 \mathrm{ab}}\right)$ & $\mathrm{h}$ & $0.24 \pm 0.0096$ & $0.19 \pm 0.001^{* * *}$ & $0.65 \pm 0.017$ & $0.75 \pm 0.0184^{*}$ \\
\hline $\mathrm{B}\left(\mathrm{K}_{\mathrm{el}}\right)$ & $\mathrm{h}^{-1}$ & $0.12 \pm 0.00014$ & $0.29 \pm 0.033^{* *}$ & $0.05 \pm 0.0028$ & $0.11 \pm 0.006^{* * *}$ \\
\hline $\mathrm{T}_{1 / 2 \beta}\left(\mathrm{T}_{\mathrm{e}}\right)$ & $\mathrm{h}$ & $5.79 \pm 0.066$ & $2.43 \pm 0.22^{* * *}$ & $13.3 \pm 1.4$ & $6.21 \pm 0.45^{* * *}$ \\
\hline
\end{tabular}


M. Atef et al.: The influence of flunixin on the elimination and milk residual patterns of oxytetracycline in dairy goats

Table 1. Mean kinetic parameters of OTC alone (10 mg/kg b.m.) and OTC + flunixin combination $(12 \mathrm{mg} / \mathrm{kg} \mathrm{b.m}$.) following single intravenous and intramuscular injections in goats $(\mathrm{n}=5)$ (continued)

\begin{tabular}{|c|c|c|c|c|c|}
\hline \multirow[b]{2}{*}{ Parameter } & \multirow[b]{2}{*}{ Unit } & \multicolumn{2}{|c|}{ Intravenous } & \multicolumn{2}{|c|}{ Intramuscular } \\
\hline & & OTC & $\mathrm{OTC}+\mathrm{FM}$ & OTC & $\mathrm{OTC}+\mathrm{FM}$ \\
\hline $\mathrm{K}_{12}$ & $h^{-1}$ & $1.87 \pm 0.04$ & $3.26 \pm 0.019^{* *}$ & NA & NA \\
\hline $\mathrm{K}_{21}$ & $\mathrm{~h}^{1}$ & $0.61 \pm 0.017$ & $1.35 \pm 0.1^{* *}$ & NA & NA \\
\hline $\mathrm{V}_{\mathrm{c}}$ & L. $\mathrm{g}^{-1}$ & $0.29 \pm 0.004$ & $0.23 \pm 0.0021$ & NA & NA \\
\hline $\mathrm{C}_{\max }$ & $\mu \mathrm{g} / \mathrm{mL}$ & NA & NA & $3.17 \pm 0.12$ & $3.79 \pm 0.2^{*}$ \\
\hline $\mathrm{T}_{\max }$ & $\mathrm{h}$ & NA & NA & $2.76 \pm 0.23$ & $2.68 \pm 0.04$ \\
\hline $\mathrm{V}_{\mathrm{d}(\text { area) }}$ & L.kg $^{-1}$ & $1.63 \pm 0.0114$ & $0.72 \pm 0.026^{* * *}$ & NA & NA \\
\hline $\mathrm{V}_{\mathrm{d}(\mathrm{ss})}$ & L.kg $^{-1}$ & $1.13 \pm 0.0081$ & $0.61 \pm 0.03^{* * *}$ & NA & NA \\
\hline $\mathrm{Cl}_{\text {tot }}$ & $\mathrm{L} \mathrm{h}^{-1} \mathrm{~kg}^{-1}$ & $0.16 \pm 0.0001$ & $0.20 \pm 0.007^{* * * *}$ & NA & NA \\
\hline AUC & $\mu \mathrm{g} \cdot \mathrm{mL} \cdot \mathrm{h}^{-1}$ & $63.2 \pm 0.72$ & $47.5 \pm 1.58^{* *}$ & $68.6 \pm 3.1$ & $46.4 \pm 2.4^{* * *}$ \\
\hline MRT & $\mathrm{h}$ & $6.75 \pm 0.009$ & $3.01 \pm 0.118^{* * *}$ & $19.07 \pm 1.2$ & $9.04 \pm 0.5^{* * *}$ \\
\hline $\mathrm{F}$ & $\%$ & NA & NA & $107.2 \pm 3.3$ & $97.29 \pm 5.1$ \\
\hline
\end{tabular}

$\alpha$ - distribution rate constant; $\beta$ - rapid elimination rate constant; $\mathrm{k}_{\mathrm{ab}}$ - absorption rate constant; $\mathrm{k}_{\mathrm{e}}$ - elimination rate constant kel; $\mathrm{T}_{1 / 2 \alpha}$ - distribution half-life; $\mathrm{T}_{1 / 2 a b}$ - absorption half-life; $\mathrm{T}_{1 / 2 \beta}$ rapid elimination half-life; $\mathrm{T}_{1 / 2}$ - elimination half-life; $\mathrm{K}_{12}$ and $\mathrm{K}_{21}$ - first-order rate constants for drug distribution between the central and shallow peripheral compartments; $\mathrm{V}_{\mathrm{c}}$ - volume of the central compartment; $\mathrm{C}_{\max }$ - peak drug concentration; $\mathrm{T}_{\max }$ - time to peak concentration; $\mathrm{Vd}_{(\text {area) }}$ - volume of distribution calculated by area method; $\mathrm{V}_{\mathrm{d}(\mathrm{SS})}$ volume of distribution at steady state; $\mathrm{Cl}_{\text {tot }}$ - total body clearance; $\mathrm{AUC}$ - area under the curve from zero to infinity by the trapezoidal integral; MRT - mean residence time in serum; and F - the systemic bioavailability. NA; not applicable; *Significant at $\mathrm{P} \leq 0.05$; ** Significant at $\mathrm{P} \leq 0.01$; *** Significant at $\mathrm{P} \leq 0.001$.

Table 2. Mean concentration of OTC $(\mu \mathrm{g} / \mathrm{mL}) \pm$ SE in urine following single intravenous and intramuscular injection of OTC (10 mg/kg b.m.) and OTC + FM combination ( $12 \mathrm{mg} / \mathrm{kg}$ b.m. $)$ in goats $(n=5)$

\begin{tabular}{|c|c|c|c|c|}
\hline \multirow{2}{*}{$\begin{array}{c}\text { Time of } \\
\text { Sampling }\end{array}$} & \multicolumn{2}{|c|}{ Intravenous } & \multicolumn{2}{c|}{ Intramuscular } \\
\cline { 2 - 5 } & $(\mathrm{OTC})$ & $(\mathrm{OTC}+\mathrm{FM})$ & $(\mathrm{OTC})$ & $(\mathrm{OTC}+\mathrm{FM})$ \\
\hline $30 \mathrm{~min}$ & $731 \pm 35$ & $851 \pm 29^{*}$ & $126.9 \pm 5.006$ & $221 \pm 20.4^{* *}$ \\
\hline $1 \mathrm{~h}$ & $528.5 \pm 15.6$ & $610 \pm 22.4^{* *}$ & $210.4 \pm 14.36$ & $390 \pm 30.0^{* * *}$ \\
\hline $2 \mathrm{~h}$ & $318 \pm 16.8$ & $407 \pm 26.0^{*}$ & $263.4 \pm 23.2$ & $430 \pm 32^{* *}$ \\
\hline $4 \mathrm{~h}$ & $191.6 \pm 15$ & $210 \pm 20$ & $313 \pm 26.5$ & $570 \pm 21^{* * *}$ \\
\hline $6 \mathrm{~h}$ & $152.6 \pm 12.4$ & $130 \pm 11$ & $248.8 \pm 22.4$ & $490 \pm 40^{* * *}$ \\
\hline $8 \mathrm{~h}$ & $131 \pm 7.60$ & $105 \pm 6.4^{*}$ & $230 \pm 29.5$ & $330 \pm 22^{*}$ \\
\hline $10 \mathrm{~h}$ & $95 \pm 8.40$ & $66 \pm 5.2^{*}$ & $224 \pm 21.8$ & $250 \pm 20$ \\
\hline $12 \mathrm{~h}$ & $61.4 \pm 4.20$ & $44 \pm 4.2^{*}$ & $197 \pm 8.1$ & $170 \pm 7.2^{*}$ \\
\hline $24 \mathrm{~h}$ & $23 \pm 2.10$ & $17 \pm 1.2^{*}$ & $60.4 \pm 5.3$ & $45 \pm 3.0^{*}$ \\
\hline $48 \mathrm{~h}$ & $12 \pm 1.10$ & $6 \pm 0.35^{* * *}$ & $16.6 \pm 1.9$ & $10 \pm 0.98^{*}$ \\
\hline $72 \mathrm{~h}$ & $2.0 \pm 0.10$ & $0.5 \pm 0.039^{* * *}$ & $5.4 \pm 0.45$ & $2.5 \pm 0.1^{* * *}$ \\
\hline
\end{tabular}

*Significant at $\mathrm{P} \leq 0.05 * *$ Significantat $\mathrm{P} \leq 0.01 ; * * *$ Significant at $\mathrm{P} \leq 0.001$

Vet. arhiv 89 (2), 155-168, 2019 
M. Atef et al.: The influence of flunixin on the elimination and milk residual patterns of oxytetracycline in dairy goats

Table 3. Mean concentration of OTC $(\mu \mathrm{g} / \mathrm{mL}) \pm$ SE. in milk following single intravenous and intramuscular injection of OTC (10 mg/kg b.m.) and OTC + FM combination (12 mg/kg b.m.) in goats with OTC milk/serum $(\mathrm{M} / \mathrm{S})$ ratio

\begin{tabular}{|l|c|c|c|c|c|c|c|c|}
\hline \multirow{2}{*}{$\begin{array}{l}\text { Time of } \\
\text { sampling }\end{array}$} & \multicolumn{4}{|c|}{ Intravenous } & \multicolumn{4}{|c|}{ Intramuscular } \\
\cline { 2 - 10 } & $(\mathrm{OTC})$ & $\mathrm{M} / \mathrm{S}$ & $(\mathrm{OTC}+\mathrm{FM})$ & $\mathrm{M} / \mathrm{S}$ & $(\mathrm{OTC})$ & $\mathrm{M} / \mathrm{S}$ & $(\mathrm{OTC}+\mathrm{FM})$ & $\mathrm{M} / \mathrm{S}$ \\
\hline $30 \mathrm{~min}$ & $0.79 \pm 0.04$ & 0.07 & $0.10 \pm 0.009^{* * *}$ & 0.01 & $0.40 \pm 0.02$ & 0.21 & $0.14 \pm 0.01^{* * *}$ & 0.05 \\
\hline $1 \mathrm{~h}$ & $1.36 \pm 0.02$ & 0.22 & $0.40 \pm 0.021^{* * *}$ & 0.05 & $0.57 \pm 0.04$ & 0.22 & $0.40 \pm 0.02^{* *}$ & 0.14 \\
\hline $2 \mathrm{~h}$ & $1.51 \pm 0.03$ & 0.27 & $0.58 \pm 0.037^{* * *}$ & 0.09 & $0.70 \pm 0.04$ & 0.23 & $0.58 \pm 0.03^{*}$ & 0.16 \\
\hline $4 \mathrm{~h}$ & $1.91 \pm 0.03$ & 0.41 & $0.94 \pm 0.035^{* * *}$ & 0.27 & $1.59 \pm 0.06$ & 0.53 & $0.67 \pm 0.03^{* * *}$ & 0.17 \\
\hline $6 \mathrm{~h}$ & $2.06 \pm 0.07$ & 0.58 & $1.13 \pm 0.10^{* * *}$ & 0.46 & $1.95 \pm 0.0$ & 0.66 & $1.08 \pm 0.09^{* * *}$ & 0.34 \\
\hline $8 \mathrm{~h}$ & $1.46 \pm 0.05$ & 0.56 & $0.80 \pm 0.04^{* * *}$ & 0.65 & $2.10 \pm 0.06$ & 0.83 & $1.19 \pm 0.03^{* * *}$ & 0.48 \\
\hline $10 \mathrm{~h}$ & $1.20 \pm 0.04$ & 0.77 & $0.58 \pm 0.03^{* * *}$ & 0.73 & $1.80 \pm 0.10$ & 0.91 & $0.70 \pm 0.03^{* * *}$ & 0.39 \\
\hline $12 \mathrm{~h}$ & $1.16 \pm 0.11$ & 0.86 & $0.3 \pm 0.025^{* * *}$ & 0.60 & $1.20 \pm 0.02$ & 1.09 & $0.40 \pm 0.02^{* * *}$ & 0.27 \\
\hline $24 \mathrm{~h}$ & $0.70 \pm 0.05$ & & $\mathrm{ND}$ & & $0.96 \pm 0.03$ & 0.90 & $0.17 \pm 0.01^{* * *}$ & 0.44 \\
\hline $48 \mathrm{~h}$ & ------- & & $\mathrm{ND}$ & & $0.36 \pm 0.03$ & & $\mathrm{ND}$ & \\
\hline
\end{tabular}

*Significant at $\mathrm{P} \leq 0.05$; **Significantat $\mathrm{P} \leq 0.01$; ***Significant at $\mathrm{P} \leq 0.001 ; \mathrm{ND}$ - not detected

Table 4. Mean concentration of OTC $(\mu \mathrm{g} / \mathrm{mL}) \pm$ S.E. in ruminal juice following single intravenous and intramuscular injection of OTC $(10 \mathrm{mg} / \mathrm{kg}$ b.m. $)$ and OTC + FM combination $(12 \mathrm{mg} / \mathrm{kg}$ b.m.) in goats with OTC ruminal juice/serum $(\mathrm{R} / \mathrm{S})$ ratio

\begin{tabular}{|c|c|c|c|c|c|c|c|c|}
\hline \multirow{2}{*}{$\begin{array}{c}\text { Time of } \\
\text { sampling }\end{array}$} & \multicolumn{4}{|c|}{ Intravenous } & \multicolumn{4}{c|}{ Intramuscular } \\
\cline { 2 - 9 } & $(\mathrm{OTC})$ & $\mathrm{R} / \mathrm{S}$ & $(\mathrm{OTC}+\mathrm{FM})$ & $\mathrm{R} / \mathrm{S}$ & $(\mathrm{OTC})$ & $\mathrm{R} / \mathrm{S}$ & $(\mathrm{OTC}+\mathrm{FM})$ & $\mathrm{R} / \mathrm{S}$ \\
\hline $1 \mathrm{~h}$ & $7.6 \pm 0.4$ & 1.22 & $4.97 \pm 0.39^{* *}$ & 0.46 & $1.2 \pm 0.09$ & 0.45 & $0.7 \pm 0.02^{* * *}$ & 0.24 \\
\hline $2 \mathrm{~h}$ & $6.1 \pm 0.5$ & 1.07 & $3.72 \pm 0.25^{* *}$ & 0.59 & $1.9 \pm 0.1$ & 0.64 & $1.3 \pm 0.1^{* *}$ & 0.36 \\
\hline $4 \mathrm{~h}$ & $4.5 \pm 0.19$ & 0.97 & $3.5 \pm 0.27^{*}$ & 1.01 & $2.3 \pm 0.2$ & 0.76 & $1.9 \pm 0.12$ & 0.49 \\
\hline $6 \mathrm{~h}$ & $4.0 \pm 0.25$ & 1.13 & $3.0 \pm 0.15^{*}$ & 1.23 & $2.9 \pm 0.02$ & 0.98 & $2.3 \pm 0.2^{*}$ & 0.72 \\
\hline $8 \mathrm{~h}$ & $3.1 \pm 0.29$ & 1.19 & $2.8 \pm 0.1$ & 2.26 & $1.6 \pm 0.15$ & 0.63 & $1.3 \pm 0.01^{*}$ & 0.52 \\
\hline
\end{tabular}

*Significant at $\mathrm{P} \leq 0.05$; **Significantat $\mathrm{P} \leq 0.01$; *** Significant at $\mathrm{P} \leq 0.001$

\section{Discussion}

The OTC serum concentrations after $\mathrm{i} / \mathrm{v}$ injection of either alone or in combination with FM in dairy goats were best depicted by the two compartments open model, which is consistent with previous studies on OTC in goats (ESCUDERO et al., 1994; ELSHEIKH et al., 1997). However, a few authors have reported that OTC fitted into a three-compartment model in veal calves (MEIJER et al., 1993). In the present study, the therapeutic level of OTC estimated in the blood of goats overlapped its MIC $0.5 \mathrm{mg} / \mathrm{l}$ (LUTHMAN and JACOBSSON, 1982) for more than 24 hours when injected either alone 
M. Atef et al.: The influence of flunixin on the elimination and milk residual patterns of oxytetracycline in dairy goats

or in combination with FM. This result is in agreement with those reported for OTC when co-administered with diclofenac in cattle (MESTORINO et al., 2007). The volumes of distribution of OTC in the central compartment $\mathrm{Vc}$, were 0.28 and $0.23 \mathrm{~L} / \mathrm{kg}$ for OTC alone and in combination with FM, respectively. These values are close to those reported in cows of $0.24 \mathrm{~L} / \mathrm{kg}$ (BRETZALFF et al., 1982) and are lower than that recorded in goats of $0.45 \mathrm{~L} / \mathrm{kg}$ (ELSHEIKH et al., 1997). The high Vd values of OTC indicated that the drug is highly distributed in the extravascular tissues. However, the (Vdarea) and (Vdss) for OTC combined with FM reported in the present study $(0.72$ and $0.61 \mathrm{~L} / \mathrm{kg}$ respectively) are significantly lower than those of OTC alone. Similar observations were reported when FM was given with sulphadimidine in horses (EL BANNA, 1999).

The elimination half-life $\left(\mathrm{T}_{1 / 2 \beta}\right)$ of OTC alone $(5.79 \mathrm{~h})$ was higher than that of OTC combined with FM $(2.43 \mathrm{~h})$. The value of $\left(\mathrm{T}_{1 / 2 \beta}\right)$ for OTC alone is similar to that reported in cows (BRETZALFF et al., 1982) and goats (ELSHEIKH et al., 1997). The mean AUC, MRT and Vd were considerably reduced, although the total body clearance was increased in FM-treated-groups. As NSAIDs inhibit prostaglandin synthesis in the body, they may modify the renal excretion of other drugs administered. Thus, the renal blood flow and renin release are altered, and the rate of elimination is changed (VERBEECK, 1990). The peaks of OTC serum concentration after $\mathrm{i} / \mathrm{m}$ injection were 3.17 and $3.79 \mu \mathrm{g} / \mathrm{mL}$ and were attained at nearly $\mathrm{T}_{\max }(2.68$ and $2.76 \mathrm{~h}$ alone and with FM, respectively). Coadministration of FM significantly shortened the $\mathrm{T}_{1 / 2 \mathrm{el}}$ and MRT of OTC (6.21 and $9.04 \mathrm{~h}$, respectively) versus those of OTC alone (13.3 and $19.07 \mathrm{~h}$, respectively). The plasma peak time recorded in this study was close to that previously reported in goats (ELSHEIKH et al., 1997). The OTC serum concentrations were higher than the MIC for 12 hours against most susceptible pathogens in both groups. FM increased the OTC concentrations after i.m injection during the first four hours sampling. This finding supported the results of TSIVOU et al. (2005), who showed that the NSAIDs diclofenac and ibuprofen raised the blood levels of cephalosporins. The authors explained this finding on the basis of the greater serum and tissue proteins binding affinity of NSAIDs than cephalosporins. Therefore, NSAIDs apparently have an antagonistic effect on binding ability, resulting in higher concentrations of free antibiotics in the blood, consequently enhancing their metabolism and elimination. The systemic bioavailability (F\%) scores of OTC after $\mathrm{i} / \mathrm{m}$ injections alone or with FM in dairy goats were $107.2 \%$ and $97.29 \%$ respectively, suggesting excellent absorption from the site of injection. These results were close to those reported by McELROY et al. (1987) in rabbits, but higher than those reported by ESCUDERO et al. (1994) in goats. Regarding the effect of FM on the kinetic disposition of OTC, our results are consistent with those reported previously (GROPPO et al., 2004; ABO-EL-SOOUD and AL-ANATI, 2011) concerning the effects of NSAIDs on the disposition kinetics of various antibacterials. 
M. Atef et al:: The influence of flunixin on the elimination and milk residual patterns of oxytetracycline in dairy goats

The bounded fraction of OTC with serum proteins was $18.73 \%$, indicating that OTC binds loosly in blood albumen in goats. This leads to an increase in free OTC levels, which increases their distribution and excretion processes. The increased elimination and reduction values of MRT of OTC after its concurrent injection with FM could be explained by the findings in TSIVOU et al. (2005), and may be attributed to the increased level of OTC due to its displacement from protein-bound sites in the presence of FM.

Approximately $70 \%$ of the dose is eliminated in urine. The increased urinary concentration of OTC indicates that it has higher efficacy against pathogenic organisms invading the urinary tract of diseased animals. The use of FM in combination with OTC did not alter the duration of its antibacterial activity $(>0.5 \mu \mathrm{g} / \mathrm{mL}$ for most susceptible bacteria) in goat's urine ( $72 \mathrm{~h}$. following $\mathrm{i} / \mathrm{v}$ and $\mathrm{i} / \mathrm{m}$ injections of both treatments). The concomitant use of OTC and FM is more favourable for urinary tract pathogens in ruminants, as confirmed by the present findings. In this respect, MEVIUS et al. (1986) found that approximately $88.0 \%$ of the OTC dose administered was eliminated from the kidneys within $72 \mathrm{~h}$. Moreover, they reported that the OTC clearance was twice as great as creatinine clearance, showing that glomerular filtration is the main pathway of elimination of OTC followed, to a lesser extent, by tubular secretion.

The concentrations of OTC in the milk were much lower than those in the urine. FM induced a significant reduction in the concentrations of OTC in milk. Drugs cross the blood-milk barrier by passive diffusion according to the physicochemical properties of the drug (ATKINSON and BEGG, 1990). In addition, the low lipophilicity of OTC delays its passage through lipid layers of blood-milk barriers, and its passage is mainly through large pores. MEVIUS et al. (1986) stated that less than $2 \%$ of the dose administered was excreted in milk.

The presence of OTC residues in milk interferes with the manufacturing of dairy products by inhibiting starter activity, which can lead to economic losses (HAYS, 2003). The existence of measurable OTC residues in milk was detected two days after $\mathrm{i} / \mathrm{m}$ administration. A parallel finding was reported by RULE et al. (2001) in healthy Murciano-Granadina goats.

The present investigation revealed that OTC concentrations were detected in ruminal juice for 8 hours after administration via both routes. As in the milk, the concomitant administration of FM with OTC induced a significant reduction in ruminal juice concentrations of OTC. The explanation for this observation may be similar to that for the OTC concentrations in milk, with the acidic $\mathrm{pH}$ of ruminal juice $(\mathrm{pH}$ 6.3) leading to a subsequent increased back diffusion of the drug to the blood. The lower concentration of OTC in the ruminal juice of animals treated with the OTC + FM combination is more beneficial than in goats treated with OTC alone, due to the reduced inhibitory effect of the former on ruminal microflora. The relatively higher OTC concentration in ruminal 
M. Atef et al.: The influence of flunixin on the elimination and milk residual patterns of oxytetracycline in dairy goats

juice than in milk could be attributed to the additional excretion of OTC in saliva (ATEF et al., 1981).

In conclusion, OTC is eliminated primarily through the kidneys and, to a lesser extent, via milk and ruminal juice in dairy goats. Milk obtained from OTC-treated goats may not be safe for human consumption for two days post-administration. Concomitantly, the use of FM with OTC may necessitate the surveillance and optimization of OTC dosages. Further studies are necessary to investigate these variations after the administration of multiple doses.

\section{Conflicts of interest}

The authors declare that there are no conflicts of interest.

\section{References}

ABO EL-SOOUD, K., L. AL-ANATI (2011): Effect of flunixin on the disposition of enrofloxacin in calves. Insight Vet. Res. 1, 1-4.

DOI: 10.5567/VETRES-IK.2011.1.4

ASZALOS, A. (1985): Fast determination of tetracycline antibiotics in different fast determination of tetracycline antibiotics in different media by High-Performance Liquid Chromatography. Chromatographia 20, 313-322.

DOI: $10.1007 / \mathrm{BF} 02310389$

ATEF, M., A. A. SALEM, S. A. AL-SAMARRAE, S. A. ZAFER (1981): Ruminal and salivary excretion of some sulphonamides in cows and their effect on rumen flora. J. Vet. Med. A. 28, 113-121.

DOI: $10.1111 / \mathrm{j} .1439-0442.1981 . t b 01170 . x$

ATKINSON, H., E. BEGG (1990): Prediction of drug distribution into human milk from physicochemical characteristics. Clin. Pharmacokinet. 218, 151-167.

DOI: 10.2165/00003088-199018020-00005

ATTAIE, R., M. BSHARAT, A. MORA-GUTIERREZ (2016): Applicability of screening tests for oxytetracycline in the milk of three breeds of goats. J. Food Prot. 79, 1013-1020. DOI: $10.4315 / 0362-028 X . J F P-15-200$

BAGGOT, J. D. (1977): Principles of Drug Disposition in Domestic Animals: The Basis of Veterinary Clinical Pharmacology. Saundary, Philadelphia, USA, pp. 144-218.

BRETZALFF, K. N., R. S. OTT, G. D. KORITZ, R. F. BEVILL, R. V. SALAWELY, B. K. GUSTAVASSON, L. E. DAVIS (1982): Pharmacokinetics of oxytetracycline in cows. Am. J. Vet. Res. 43, 12-16.

CRAIG, A. W., B. SUH (1980): Protein binding and the antibacterial effects, In: Antibiotics in Laboratory Medicine. Baltimore, Maryland, Williams and Wilkins, pp. 265-297. 
M. Atef et al.: The influence of flunixin on the elimination and milk residual patterns of oxytetracycline in dairy goats

DOHERTY, M. L., A. M. HEALY, M. SHERLOCK, L. CROMIE, G. McELVOGUE (2001): Combined oxytetracycline-flunixin therapy in field cases of acute bovine respiratory disease. Irish Vet. J. 54, 232-238.

EL BANNA, H. A. (1999): Pharmacokinetic interactions between flunixin and sulphadimidine in horses. Dtsch. Tierarztl. Wschr. 106, 400-403.

ELSHEIKH, H. A., I. A. OSMAN, B. H. ALI (1997): Comparative pharmacokinetics of ampicillin trihydrate, gentamicin sulphate and oxytetracycline hydrochloride in Nubian goats and desert sheep. J. Vet. Pharmacol. Therap. 20, 262-266.

DOI: $10.1046 / j .1365-2885.1997 .00061 . x$

ESCUDERO, E., C. M. CARCELES, J. M. SERRANO (1994): Pharmacokinetics of oxytetracyline in goats, modification induced by long-acting formulation. Vet. Rec. 135, 548-552.

GIBALDI, P., D. PIERRIER (1982): Pharmacokinetics, $2^{\text {nd }}$ ed. Marcel Dekker Inc., New York, USA.

GIGUÈRE, S., J. F. PRESCOTT, P. M. DOWLING (2013): Antimicrobial Therapy in Veterinary Medicine, John Wiley \&Sons, Inc $5^{\text {th }}$ ed. Ames, IA, USA, Iowa State University Press, p. 257. DOI: $10.1002 / 9781118675014$

GRAIGMILL, A. L., R. E. HOLLAND, D. ROBINSON, S. WETZLICH, T. ARND (2000): Serum pharmacokinetics of oxytetracycline in sheep and calves and tissue residues in sheep following a single intramuscular injection of a long-acting preparation. J. Vet. Pharmacol. Therap. 23, 345-352.

DOI: $10.1046 / \mathrm{j} .1365-2885.2000 .00292 . \mathrm{x}$

GROPPO, F. C., R. P. SIMOES, J. C. RAMACCIATO, V. REHDER, E. D. ANDRADE, T. R. MATTOS-FILHO (2004): Effect of sodium diclofenac on serum and tissue concentration of amoxycillin on staphylococcal infection. Biol. Pharmaceut. Bull. 27, 52-55.

DOI: $10.1248 / \mathrm{bpb} .27 .52$

HALLOY, D. J., C. CAMBIER, P. G. GUSTIN (2006): Efficacy of ceftiofur and flunixin in the early treatment of bronchopneumonia in weaners. Vet. Res. 158, 291-296.

DOI: $10.1136 /$ vr.158.9.291

HAYS, F. A. (2003): Effect of drugs on milk and fat production. J. Agric. Res. 3, 122-123.

KNOX, H., D. J. JAURAND (1979): Mechanism of reversed-phase separation of tetracyclines by HPLC. J. Chromato. 186, 763-781.

DOI: 10.1016/S0021-9673(00)95294-4

KUKANICH, B., R. GEHRING, A. I. WEBB, A. L. CRAIGMILL, J. E. RIVIERE (2005): Effect of formulation and route of administration on tissue residues and withdrawal times. J. Am. Vet. Med. Assoc. 227, 1574-1577.

DOI: 10.2460/javma.2005.227.1574 
M. Atef et al.: The influence of flunixin on the elimination and milk residual patterns of oxytetracycline in dairy goats

LANDONI, M., F. CUNNINGHAM, P. LEES (1995): Determination of pharmacokinetics and pharmacodynamics of flunixin in calves by use of pharmacokinetic/pharmacodynamic modeling. Am. J. Vet. Res. 56, 786-794.

LOCKWOOD, P. W., J. C. JOHNSON, T. L. KATZ (2003): Clinical efficacy of flunixin, carprofen and ketoprofen as adjuncts to the antibacterial treatment of bovine respiratory disease. Vet. Rec. 152, 392-394.

DOI: $10.1136 /$ vr.152.13.392

LUTHMAN, J., S. A. JACOBSSON (1982): Comparison of two oxytetracycline formulation in cattle. Acta Vet. Scand. 31, 97-99.

McELROY, D. E., W. R. RAVIS, C. H. CLARK (1987): Pharmacokinetics of oxytetracycline hydrochloride in rabbits. Am. J. Vet. Res. 48, 1261-1263.

MEIJER, J. A., K. G. CEYSSENS, W. T. LONG, B. I., GREVE (1993): Three phase elimination of oxytetracycline in veal calves, the presence of an extended terminal elimination phase. J. Vet. Pharmacol. Therap. 16, 214-222.

DOI: $10.1111 / j .1365-2885.1993 . t b 00166 . x$

MESTORINO, N., E. MARINO-HERNADEZ, L. MARCHETTI, J. O. ERRECALDE (2007): Pharmacokinetics and tissue residues of an oxytetracycline/diclofenac combination in cattle. Rev. Sci. Tech. Int. Epiz. 28, 679-690.

MEVIUS, D. J., J. F. NOUWS, H. J. BREUKINK, T. B. VREE, F. DRIESSENS, R. VERKAIK (1986): Comparative pharmacokinetics, bioavailability and renal clearance of five parenteral oxytetracycline - $20 \%$ formulations in dairy cows. Vet. Q. 8, 285-294.

DOI: $10.1080 / 01652176.1986 .9694057$

RULE, R., L. MORENO, J. M. SERRANO, A. G. ROMAN, R. MOYANO, J. GARCIA, (2001): Pharmacokinetics and residues in milk of oxytetracyclines administered parenterally to dairy goats. Aust. Vet. J. 79, 492-496.

DOI: $10.1111 / j .1751-0813.2001 . t b 13023 . x$

TSIVOU, E., I. MELAKOPOULOS, A. KOTSIOU, S. ANAGNOSTOPOULOU, C. TESSEROMATIS (2005): Alterations in cefalosporin levels in the serum and mandible of hyperlipidemic rats after coadministration of ibuprofen. Eur. J. Drug Metab. Pharmacokinet. 30, 171-174.

DOI: 10.1007/BF03190616

VERBEECK, R. K. (1990): Pharmacokinetic drug interactions with nonsteroidal anti-inflammatory drugs. Clin. Pharmacokinet. 19, 44-66.

DOI: 10.2165/00003088-199019010-00004

Received: 13 December 2017

Accepted: 21 March 2019

Vet. arhiv 89 (2), 155-168, 2019 
M. Atef et al.: The influence of flunixin on the elimination and milk residual patterns of oxytetracycline in dairy goats

\begin{abstract}
ATEF, M., A.-B. Y. I. EL-GENDI, N. A. AFIFI, K. ABO-EL-SOOUD, H. Y. ELZORBA: Utjecaj fluniksina na uklanjanje i dinamiku rezidua oksitetraciklina u mlijeku mliječnih pasmina koza. Vet. arhiv 89, 155-168, 2019.
\end{abstract}

\title{
SAŽETAK
}

Istražen je utjecaj fluniksina-meglumina (FM) na uklanjanje i rezidualna svojstva oksitetraciklina (OTC) u mlijeku mliječnih pasmina koza. OTC je dan jednokratno intravenski i intramuskularno u dozi od $10 \mathrm{mg} /$ kg tjelesne mase. Serum, urin, mlijeko i buražni sok analizirani su tekućinskom kromatografijom visoke učinkovitosti (HPLC). Koncentracije OTC u serumu bile su tijekom 12 sati više od najmanje inhibitorne koncentracije za najosjetljivije patogene u objema skupinama. Vrijeme polurazgradnje OTC-a $\left(\mathrm{T}_{1 / 2 \alpha}\right)$ bilo je 0,24 sata, a vrijeme uklanjanja $\left(\mathrm{T}_{1 / 2 \beta}\right) 5,79$ sati. Vrijeme potpunog uklanjanja OTC-a statistički znakovito je poraslo u skupinama kojima je istodobno dan i fluniksin-meglumin. Nakon intramuskularne injekcije poluvijek apsorpcije $\left(\mathrm{T}_{1 / 2 a b}\right)$ s maksimalnim vremenom apsorpcije $\left(\mathrm{T}_{\max }\right)$ pokazao je veću brzinu apsorpcije. Osim toga sistemska bioraspoloživost ( $\mathrm{F} \%$ ) nakon intramuskularne primjene bila je 107,2 \% što upućuje na potpunu apsorpciju iz mišićnih tkiva. Dio OTC-a vezan na serumske proteine iznosio je 18,73\%. Fluniksin-meglumin statistički znakovito je smanjio koncentracije OTC-a u mlijeku i buražnom soku. OTC je uklonjen ponajprije putem bubrega i, u manjoj mjeri, mlijekom i buražnim sokom u mliječnih pasmina koza. Mlijeko dobiveno od koza kojima je davan OTC nije prikladno za upotrebu u ljudi do dva dana nakon primjene. Istodobna primjena FM-a s OTC-om može zahtijevati praćenje i optimizaciju OTC doze.

Ključne riječi: oksitetraciklin; fluniksin-meglumin; uklanjanje; mlijeko; rezidue; koze 